\title{
LITERATURE FOR 1915 ON THE BEHAVIOR OF SPIDERS AND INSECTS OTHER THAN ANTS
}

\author{
C. H TURNER
}

Sumner Hzgh School, St. Louis, Mo

TROPISMS AND RELATED PHENOMEXA

Essenberg (33) finds that the back-swimmers are negatively geotactic, negatively geotropic, positively phototactic and positively rheotactic, and that the water-striders (34) are positively. phototactic, negatively geotactic, positively thigmotactic and positively rheotactic.

Krecker's experiments (73) show that Hexagcnia variabilis behaves as though it were negatively anemotropic, negatively geotropic and negatively phototropic.

Áccording to Blackman (14) a strong light causes Pityogcncs hopkinsi to stop work; but frequent repetitions of the stimulus soon produce no visible effect on the animal.

Hargitt (56) finds in the mourning-cloak butterfly a dominance of the chemotropic response to food and a slight negative phototropism, and Howlett (65) discusses the chemical reactions of fruit-flies.

According to Zetek (130) phototropic responses dominate the flight of the malaria spreading mosquitoes.

Turner states (119) "The ant-lion may be considered positively geotactic, positively thigmotactic and negatively phototactic, with the reservation that all of its movements cannot be explained as tropisms in the Loebian sense."

Girault (49) placed some specimens of Trichogramma minutum in a glass jar which was equally lighted on all sides. They chmbed the sides of the jar; and, when it was slowly reversed, they turned so as to continue upwards. Evidently they are negatively geotactic.

McDermott (84) caused a warm current of air to impinge on a dish containing material attractive to flies. The enticed flies would walk along until within two or three centimeters of the 
point where the air struck the dish. There, facing the current they would pause with outstretched wings. Sometimes two or three would be in a row. Either a sudden stopping of the current or increasing the temperature to forty degrees centigrade would cause them to disperse.

Kincaid (69) finds that the color of the environment of the larva has a pronounced effect upon the color of both larva and pupa of the thistle butterfly. Caterpillars of this species were placed in boxes of the following colors; pearl gray, lavender, crushed apricot, blue, pink, green and black. The larvae placed in the gray boxes became light gray. Those in the black boxes became black and formed black chrysalids with a sprinkling of gold. Those in the green boxes turned black; but their chrysalids were dark brown. Those in the blue boxes acquired brown bodies with bluish spines and their chrysalids were brown with gold spots. Those confined to the lavender and to the pink boxes developed stripes about the color of the boxes; but the chrysalids of the first were light tan with gold spots and those of the latter almost all gold. Those in the apricot boxes evolved stripes and spines that matched perfectly the color of the box and the chrysalids were the exact color of the box, with two rows of gold spots. The adults did not seem to be affected at all by the color of the environment of the larvae.

\section{OLFACTORY SENSATIONS}

Small drops of coal oil and of ammoniun were placed on the upper edge of an aquarium containing water-striders. When the insects approached these substances, they waved their antennae and dropped into the water. These reactions caused Essenberg (34) to predicate a sense of smell to water-striders.

To test the olfactory sense of beetles, McIndoo (85) isolated them in small triangular boxes with netting bottoms. He used 434 individuals belonging to eleven species and eight families. From some he removed the antennae; from others, the elytra; from others, the wings; from others, one or more legs. "Four unmutilated species responded to odors more slowly than did members of the same species with amputated antennae. . . . Five species without antennae responded to odors as promptly as did the same species unmutilated. . . . Two species without antennae responded to odors more slowly than did the same 
species unmutilated. Six species so mutilated that most of their olfactory pores on the elytra and wings were prevented from functioning responded from two to five times more slowly than did the same species unmutilated, or with the antennae pulled off." These results prompted the conclusion that the antennae have no olfactory function and that the pores found on the peduncles of the elytra, on the dorsal surfaces of the wings, on the trochanters, tibiae, and sometimes the femurs and tarsi, and perhaps on the mouth appendages, are the true olfactory organs of beetles. This is in accord with the same investigator's work on the Hymenoptera, which was reviewed in this journal last year.

These experiments of McIndoo are painstaking and his anatomical studies of what he calls olfactory pores are excellent; but, the serious student, who is acquainted with the experiments of Forel and others who "claim that the antennae are the organs of smell," will not be convinced that the last word has been said on the subject. They do not seem to have met the following criticisms raised by Forel* several years ago:- " To demonstrate the sense of smell, our two physical distant senses, vision and hearing, must be eliminated with certainty. But that is not sufficient. Innumerable chemical substances included in either air or in water in a state of gas (free or absorbed) can, as is known, and as I have already pointed out at the commencement of these experiments (1878), while exercising in any way some corrosive action, irritate nerve terminations other than those of olfaction, and that (at least so far as concerns man) generally in a painful or at least a disagreeable fashion." "If we are content, as our predecessors have often been, and as Graber is again, to bring close to the animal certain substances which are odorous to us, and see whether or not it avoids them, we have not demonstrated olfaction at all. We have simply shown that these substances have irritated the animal in one way or another. If the animal comes up to them instead of avoiding them we have proof that the irritation is agreeable to it. That nearly approaches olfaction, but is by no means proof of it, for certain irritations can be agreeable, without, for all that, being olfactive. It is necessary, then, as I have said, to show that the irritation in question allows

* Forel, August. The Senses of Insects. Translated by Macleod Yearsley. Methuen \& Co, London, 1908, p. 74-76. 
the animal to recognize such or such matter, to distinguish it from others in a constant and indubitable fashion. Then we have a right to speak of olfaction, and it is even in my opinion the only proof, the only definition of the sense we have."

\section{OTHER SENSES}

1. Auditory Sense. When a metallic sound is made the water striders move backwards. If a buzzing insect drops into the water, the striders rush towards it; but, they do not respond to a dead insect that falls into the water. These facts induced Essenberg (34) to believe that water-striders can hear.

2. Tactile Sense. By means of a tuning fork and of a straw attached to an electric vibrator, Barrows (12) has given a brilliant confirmation of what Dahl* discovered long ago; i. e., that spiders reach their prey by following the radius that vibrates the strongest. By amputating first one leg and then another, he demonstrated that the sense of touch is not confined to any pair of legs.

3. Vision. Works on color vision and form-perception have appeared by Buttel-Reepen (20), Frisch (41) and Stellwaag (114).

\section{MATING BEHAVIOR}

Awati (4) describes the mating behavior of the apple sucker and of the pear sucker; Back and Pemberton $(5,6)$, of the Mediterranean fruit-fly and of the melon-fly; Blackman (14), of Pityogencs lopkinsi; Chapman (23), of Agrilus bilineatus; Fuller (43), of some South African termites, Funkhouser (4t), of Vanduzca arquata Say; Gerhardt (45), of crickets and locusts; Hancock (55), of pink katydids; Kennedy (68), of dragon-flies; Rau (102), of Dichromorpha viridis; Turner (120), of the camel cricket; and Williams (127), of the pea thrips.

It is well known that the phosphorescence of the Lampyridae is a courting device. Blair (15) informs us that among the British forms it is the female that does the active courting, while in America it is the male. He also reminds us that we do not know the function of the phosphorescent light in those few forms that do not belong to the Lampyridae.

Schwarz (106) remarks that the mating behavior of Catocala

* Dahl, Frdr. Beitráge Zur Biologre der Spinnen. Zool. Anz., VII Johrg., 1883. No. $180, \mathrm{~s}$ 591-595. 
titania resembles that of the English sparrow. With his wings half spread, displaying the beautifully colored hind mings, the male performs many antics.

Sturtevant (116) has performed some experiments upon sex recognition and sexual selection in Drosoplitia ampchplita. By putting a female in one rial and a male in another and placing the vials mouth to mouth, with a cover glass between them, it was found that the male pays no attention to the female until the cover glass is removed. This observation, coupled with the fact that they mate in darkness, forces the conclusion that rision is not essential for their mating. Experiments demonstrated that the female will mate with either normal or mutilated males: but males with entire wings mate sooner than those with mutlated wings. Hence he concludes that the wings play a prominent part in arousing sexual excitement, but that there is no evidence of sexual selection. A specimen that is ready to mate will do so with the first member of the opposite sex that happens along.

\section{MATERNAL INSTINCTS}

Back and Pemberton (5, 6,7) have discussed the ovipositing of the Mediterranean fruit-fly and the melon-fly; Blackman (14), of Pitrogencs hopkmsi; Dunn (32), of Dermacentor ntcns; Essenberg (34), of the water-strider, Fuller (43), of some South African termites; Hancock (55), of katydids, Kennedy (68). of dragonflies; Schwarz (106), of Catocala tntania, and C. L. Tumer (120), of the camel cricliet.

Severin $(10 \%)$ thmks that the perception of the digestive fluids through the micropyle of the egg causes the larva of the leafovipositing Tachinidae to begin to free itself from the egg.

Hegner (58) so manipulated the eggs of the potato beetle that 35 batches were in the sunlight and 15 in the shade. All of the eggs in the shade hatched, but none of those in the sun, although 18 developed to the hatching point. Sections of the eggs showed that derelopment had proceeded in the sunlight and that the failure to hatch was probably due to dessication. He concludes: "The advantage of concealment is not so great therefore as that secured by shielding the eggs from the dessicating properties of the sun."

By adding spiders to and abstracting spiders from the nests of mud-dauber wasps, Rau (101) demonstrated that sometimes 
the spiders were removed and at others they were not. "In answer to the question suggested in the title we can only say that in most cases where the spiders were disturbed the owner was quick to detect it and frequently resented it. But, since, in her anger, she often threw away part or all of her own prey, we cannot determine whether or not she recognized her own, or merely responded, with alarm, to any meddling about her home."

\section{FOOD PROCURING ACTIVITIES}

Awati (4) describes the feeding behavior of the apple sucker and of the pear sucker; Clausen (24), of certain aphid feeding Coccinellidae; Cleare (25), of a butterfly injurious to the cocoanut palm; Funkhouser (44) , of Vanduzea arcuata Say; Gillette and Bragg (46), of some Colorado aphids with alternating feeding habits; Girault (48), of the aphid-eating Adalia 15-punctata; H. A. B. (52), of a fruit-fly attacking papaws; Haddon (53), of the larvae of the glow-worm Lampyris noctiluca; Hewitt (61), of the stable-fly; Rau (102), of Dichromorpha viridis; Shannon (108), of syrphid flies; Williams (127), of the pea thrips; and Marcovitch (89), a mite, a chalcid fly, a fruit fly, and a caterpillar that feeds on the juniper berry.

Bromley (17) gives an extensive list of the prey of eighteen species of asilids.

Sanders (105) records the fact that the larva of the fruit-fly (Xylena bethunci) eats the pupae of Malacosoma distria and $M$. americana.

Girault (47) relates the case of a bird-bug (Cimex hirudinia) which forsook the swallows of the chimney for the people sleeping in the adjoining room.

By dissections, Wheeler (126) demonstrated that the food of the New Zealand glow-worm consists of insects. He thinks the larvae catch both creeping and flying hexapods in their glutinous webs.

Richardson (103) found the larvae of a wasp dwelling in passageways in the galls of Holocaspis globosus of the oak and feeding upon plant lice. From this he concludes that the adults attend to the young throughout the entire larval period It is unfortunate that the colony was not kept under observation long enough to verify this conclusion.

By raising fleas in petri dishes, Lyon (82) discovered that the 
fleas prefer, as food, dust from the room and dried insect skins to dry blood.

It is well known that crab-spiders (Thomisidae) frequent flowers for the purpose of preying on insects. Lovell (79) discovers that they feed on bumble-bees, honey-bees, butterflies, dragon-flies, large flies and wasps.

Rau (100) finds that both the larva and adult of the mealworm eat feathers, seed and dead insects.

Zetek (130) states that the mosquitoes Anophelcs albimanus Wied. and $A$. tarsimaculata Goledi prefer human blood to any other food.

According to Essenberg (34) the water-striders feed upon a large variety of animal food, most of which is captured upon the surface of the water. Food is never secured under water and the insect will not touch larval mosquitoes. They often rest quietly upon aquatic plants and catch mosquitoes by leaping upon them. In confinement they are cannibals

Turner (119) finds that the ant-lion feeds upon a variety of small invertebrates that happen to fall into the pits which it forms in any kind of friable material that is protected from the rain Two methods are used by the ant-lions in forming these pits. "Usually it furrows backward, excavating a series of concentric, adjacent, circles, each deeper than the last, and shovelling out the soil with its head. The front of the body is so curved as to make it easy for the dirt to fall forward on the head. In the second method, the larva simply burrows downward into the ground and tosses out the soil with its head until the sides of the pit become stable. Pits formed by the second method are usually subsequently enlarged. He confirms the often discredited statement of early investigators that this insect removes obstacles from the pit by backing up the side thereof with the object balanced on its abdomen.

Lloyd (77) describes a species of caddis worm (Ganonema nigrum) which in its habits is unlike all others except a New Zealand species (Triplectides obsoleta) described by Hudson in 1904. Instead of constructing the orthodox dwelling of conglomerated stones or twigs or tubes of silk, it selects a short twig from the stream bottom, hollows it from end to end, and lines the cavity with silk. When this tube becomes too short, the insect glues it, end to end, to another twig and treats the addition 
in the same manner it did the first twig. If the added piece is too long it is shortened by girdling. The food consists of powderasped from submerged wood.

Noyes (93) has made a careful study of the net-spinning caddisworms of Caseadilla creek. She demonstrated, experimentally, that they will construct tubes even in still water; but that nets are only formed in the presence of a current. The different species of Hydropsyche construct similar nets, and the netbuilding behavior is as follows:- 1 . They construct nets by either day or night. 2. Two and a half to three hours is the average time required to complete a tube. 3. No temporary construction threads are used. 4. There is no definite order in which the threads are woven. 5. Particles are removed from the nets with the mouth parts and not with the dorsal tufts of hairs on the anal legs. 6 . The front legs and the mandibles are used for holding particles in position until they are fastened in place with silk. 7. They are never too busy weaving to stop to capture food that adheres to the net. She confirms Siltala's statement that the food of these forms is both animal and vegetable. In fall and winter diatoms form the bulk of the food; in spring and summer minute animals predominate. At all times a moderate amount of algac is consumed.

\section{ANTHOPHILY}

As a result of ten years devoted to their study in Maine and Massachusetts, Lovell $(78,80)$ reports the discovery of 332 species of anthophilous beetles belonging to 127 genera and 29 families. This is 47 species more than Knuth records for all of North America. He rrites: "In all of the families, in most of the genera and in very many of the species in which anthophily occurs this habit has been acquired independently; but in the case of Gnathinm and Nemognatha it probably arose before the genera were differentiated. Except in these two genera and to a less extent in Changlignathus and Lepturini the modifications induced are obscure and indistinct; from which it may be inferred that anthophily among the Coleoptera is of comparatively recent origin. The primitive Coleoptera lived largely upon the ground and were carnivorous, but as they learned to search for prey on plants and to feed upon vegetation anthophily became correspondingly common. As pollinators of flowers the 
anthophilous beetles are of little significance. The enormous derastation of the vegetative organs of plants by beetles both in the larval and the adult stages, the consumption and waste of pollen and nectar, the destruction of the petals and other floral members, the absence of hair for holding the pollen and their indefinite manner of flight are factors which greatly reduce their value as pollen carriers. Floral structures show absolutely no response to the visits of beetles, and there is no reason to suppose that the development of the anthophilous flora would have varied in any respect had entomophily never arisen among the Coleoptera."

\section{HIBERNATION}

Frohawk (42) discusses the hibernation of Vancssa antiopa and Nicholson (92), that of Vespa iulgaris.

According to Blackman (14) Pityogenes hopkinsi hibernates in the larval pupal and also the adult stages.

Recently three investigators have discussed the overwintering of the house-fly and they are not in accord. Lyon (81) used thirty-seven lots of 100 pupae. Some were placed in wet sand and some in $\mathrm{dry}^{+}$, some in wet manure and some in dry. some in moist loam and some in dry, and some in leaf mould. Two series were placed out of doors, one in a sheltered spot and the other in an unsheltered position; a third series was placed in a greenhouse and a fourth in a cellar. No adults emerged from the jars placed out of doors; but, by the first of December, 210 had emerged from the pupae placed in the greenhouse and 367 from those stored in the cellar. The pupae that did not emerge were found to be dead. "It would seem therefore that the appearance of the seemingly freshly-emerged adults in any considerable numbers during the late winter should be accounted for in some other way" than supposing they have over-wintered in the pupal stage.

Skinner (111) after asserting that Dr. Moncton Copeman and Mr. E. Austin claim that the adult house-fly does not hibernate in England, expresses the belief that it does not do so in Philadelphia. He bases his conclusion upon his observation that the flies seen in the Academy of Science during the winter look as though they have just emerged.

Hewitt (60) writes: "I think we are still justified in regarding the dormant and periodically active states during the over- 
wintering period as the usual occurrence in northerly latitudes. In no case have I been able to find in England or Canada living pupae of Musca domestica, under outdoor conditions, during the winter. Nor has it been possible in my breeding experiments in Canada and England to carry insects through the winter in the pupal stage. . . Until evidence is secured of the insect overwintering in the pupal stage, we shall be justified in believing, from the facts available, that in northern latitudes $M$. domestica is accustomed normally to winter in the adult stage. In more southerly latitudes, where the temperature is much higher, and where the activities of the flies are practically continuous throughout the winter months, one would expect the occurrence of insects in an active condition and of the various stages of development during this period."

\section{ECOLOGY}

Forbes (38) urges students of economic entomology to study ecology. Defining ecology "as the relation of organisms to their environment, organic and inorganic, and any and all organisms, man included-man, indeed, as by far the most important living factor, from whatever view point," he insists that these relations are three: 1st, interactions (dynamic relations); 2nd, space relations (static relations), 3rd, successional relations (genetic relations). The dynamic factor is the only one that interests the economic entomologist; and twentieth century man, as a dominant species, is an important element of that factor.

Shelford (109) reminds us that scarcely any of the pests of forage and garden crops are forest animals and that only a few of the orchard and small fruit pests are strictly so. These pests naturally fall into those that frequent moist places and those that prefer higher and drier ground. The original home of the former was the lowland about streams, lakes and marshes; while the latter originated on the steep lake and river fronts and on exposures of bare rock. Hence, originally our pests were crowded into the cracks of the forest and scattered along the river margins of the great plains. With the clearing of the land and the planting of crops the habitats of these pests were expanded.

Banks (8) writes" "Since the main orders of insects have existed on the earth the gross outlines of the continents have 
changed several times and between these changes there were migrations and dispersals, just as there is to-day. So that to-day each continent has insects which by their structure and origin are isolated from other insects around them and find their relations only in insects of distant countries " In western North Carolina there is a species of Panorpodcs, a genus whose only other habitat is Oregon and Japan. In the southern Appalachians there is a spider (Hypochilits) which occurs elsewhere only in Colorado and which has a closely related genus in North China and New Zealand. In eastern S. America there 1 is a handsome genus of ant-lions (Dimares) unlike anything else in $\mathrm{S}$. America, but is so closely related to species of a genus found in Africa, Arabia and Ceylon that one loathes to separate them. Evidently the types of insect fauna do not agree with those of mammalian and avian fauna. There are three major types of insect fauna; (1) the microtypal, including insects of Europe, N. America, N. Asia, a considerable element of Andean America, many species in India, Insuludae and New Zealand, a distinct representation in Australia and a poor development in Africa; (2) the African or Gonwandan, with its present home in Africa, but strongly developed in Australia and almost as well developed in Insulidae and Ceylon, planly present in India and noticeable in the Americas; (3) the Brazilan, with its center in Brazil. The third is a recent development; the other two are of ancient origin.

Banks analyzes the present insect fauna of the U. S A. into the following elements. (1) Genera which are the relicts of a very ancient fauna which existed when the land masses were of a different formation from now. These are isolated in our fauna and are mostly examples of discontinuous distribution. (2) Genera representing relicts of an ancient invasion from S. America possibly through the West Indies, after S. America had been connected with Africa or a Pacific continent. These genera are isolated systematically in our fauna; they are forms that look out of place among our insects and are usually represented in northern Europe neither by recent forms nor by fossils. (3) Genera originating in this country from an insect fauna of which the elements " 1 " and " 2 " are relicts. These are confined to the United States and their affinities are with S. American or Asian insects rather than with those of Europe. "I consider 
that this fauna had a long period of quiet development and became very extensive. The miocene fossils perhaps represent this fauna." (4) Genera and derivatives representing the holarctic fauna forced southward by the advance of the ice-sheet. These are the forms that show the relationship of our insect fauna to that of northern and middle Europe. The bulk of many large families belong here. (5) Genera representing a comparatively recent influx from the American tropics, a migration still in progress. He gives examples of all of these elements and closes his article with: "I doubt not but there are other elements also in our fauna; but I think these are the most noticeable, and sufficient to show that the Nearctic insect fauna is not a realm, but a conglomeration of several such realms."

\section{LETISIMULATION}

Chapman (23) states that when touched the adult Agrilus bilineatus letisimulates and drops to the ground.

According to Essenberg (34) death feigning is a characteristic of the water-strider. It crosses its forelegs and becomes perfectly rigid.

Turner (119) finds that the ant-lion letisimulates so perfectly that one can cut off the tips of its legs and even of its mandibles without inducing a response. All death-feigning poses are not death attitudes. "In the ant-lion letisimulation seems to be but an exaggeration and prolongation of the pause made by most animals when they are startled. The total behavior of the death-feigning ant-lion supports Holmes's contention that 'the instinct of death-feigning is connected with much that is called hypnotic in the lower animals,' and endorses James, when he says: 'It is really no feigning of death at all and requires no self-command. It is simply terror paralysis which has become so useful as to become hereditary.' "'

\section{MISCELLANEOUS ACTIVITIES}

Commensalism. Diguet (31) describes a case of commensalism between a spider and a beetle and another species of spider and ants. The beetles and ants seem to remove the remains of the numerous flies that become ensnared in the web.

Knab (70) records a case of commensalism in Desmometropa. Disease Spreading Activities. Articles on the relation of flies 
to diseases have been published by Hadwen (54), Hewitt (62), McShane (86), Mitzmain (90), and anonymously (1,2). Notes on the malaria spreading mosquito have appeared by Carter (22). Wheeler (125) has discussed ants and bees as bearers of pathogenic micro-organisms.

Locomotion. Zetek (130) found that the mosquito Anopheles migrates from the marshes to town at dusk and from the town to the marshes at dawn. Lloyd (77) says the wood-boring caddis worms studied by him crawl with a jerky motion. Mann (88) mentions a tick, found in the Sinaitic Peninsula and Arabia, which travels after its host at the speed of a man.

Longerity. Back and Pemberton $(5,6)$ discuss the duration of life of the Mediterranean fruit-fly and of the melon-fly: Grault (48), of Adalia 15-punctata; Lyon (82), of the cat flea; Rau (100, 102), of the meal worm and of Dichromorpha riridis.

Migrations. McAtee (83) describes a remarkable flight of caddis flies and chironomids; Webster (123) mentions migrating swarms of the milk-weed butterfly which he noticed at Ames, Iowa ${ }^{*}$ August 30 and at Waterman, Illinois, September 18, 1915.

Memory. See Rau (101) and Sturtevant (116) under maternal instincts.

Barnard (11) noticed a butterfly attempt to feed from the brightly colored eye of a peacock's feather on a man's hat.

\section{REFERENCES}

1. Axon. Fhes as a Factor in Infant Mortality. Penn. Health Bulletzn, No. 69.

2. Axos House Flies as Carriers of Disease Nature, 95, 289-292.

3 Almxander, C P. The Brology of the N. A. Crane Flies, Jour. of Entom. and Biol, 7, 1-9, 141-160.

4. Awat, P. R The Apple Sucker, with Notes on the Pear Sucker. Ann App. Biol., 1, 247-266

5. Back and Pemberton. Life History of the Mediterranean Fruit Fly from the Standpoint of Parasite Introduction. Jour. of Agr. Research, 3, 363-374.

6. Back and Pemberton Life History of the Melon-Fly (Bactrocera cucurbtae). Jour. of Aqri. Research, 3, (1914), 269-274.

7. Back, E. A. and Pemberton, C. E. Susceptibulity of Citrous Fruits to the Attacks of the Mediterranean Fruit Fly. Jour of Agr Research, 3, 311-330.

8. Banks, Nathas Geographical Distribution of Neuropteroid Inseets, with Analysis of the American Insect Fauna. Ann. Entom. Soc. of America, 8, $125-135$.

9. Banks, Nathax. Miscellaneous Notes. Proc. Entom. Soc. of Washington, 17, 146-147.

10. Barber, H. S. The Breeding Place of Dermestes elongatus. Proc. Brol. H'ashington, 27, 145-146.

11. Barnard. A Mistake of a Butterffy. Nature, 96, April, 15.

12. Barrows, William. The Reactions of an Orb-IVeaving Spider, Eperra scloptera, to Rhythmic Vibrations of the Web. Biol. Bull., 47, 316-332. 
13. Bishopp, D. and Parman. Notes on Certain Points of Economic Importance In the Biolocy of the House-Fly. Jour. of Econ. Entom., 8, 51-71.

14. Blacksan, M W Observations on the Life-History and Habits of Patyogenes hopkinsi Swaine. New York State College of Forestry, Technical Publcatzon, 16, 11-66.

15. BLAIR, K. G. Luminous Insects Nature, 96, 411-415.

16. Brocher, F. Researches sur la Respiration des Insectes Aquatiques Adultes. Les Dyticides Ann. Brol. Lacustre, 7, 5-39.

17. Bromley. Stanley W Aslids and Their Prey. Psyche (1914), 21, 192-198.

18. Braun. A F. Life Histories of N. A. Tineida. The Carad. Entom., 47, 104-108.

19. BUDDENBRock. T, Ueber das Vorbandensem des Lichtruckenreflexes bei Insecten sowie bel dem Krebse Branchipus grubez. Sitsungsberichte Hezdelberger Akad d. Wrss., Ab. 1, $10 \mathrm{pp}$.

20. Buttel-Reepex. H Haben die Bienen einen Farben und Formsinn? Die Naturumsenschaften, 13, 80-82.

21. Calinmm, M. Appetite of Slugs for Green Material The Zoologist, 1915, 159.

22 Carrer, H R. Notes on Anopheles Production from a Malarial Survey. Ancr. Jour. of Trop. Diseases and Preventire Medicine, 2, 753-758.

23. Cuapman, K. N. Observations on the Life History of Agrillus bilineatus. Jour. of Agri Research, 3, 283-294

24. Clausex, C I' A Comparative Study of a Series of Aphid-Feeding Coccmellidae Jour. Econ. Entom, 8, 487-191.

25 Cisiake, L D A Butterfly Injurious to Coroanut Palms in Br. Guana. Bull Entom. Research, 6, 273-278.

26 Constant. A. F The Habits, Lufe-History and Structure of the Bloodsucking Musced Las va (Protocallephora azurea) The Jour of Parsitology, 1, 31-150

27. Cook, A.J The Relation of Bees to Agriculture Mo. Bull State Com of liorleculture, 4, 426-427

29 Crisple, $N$ Some Inhabitants of a Sand Plum in June The Canad Entom $47,2+30$

29. CrтиввR, H. G. Selective Instinct in Bees The Irish Naturalist, 24, $185-189$

30 DAvis. J. J Cages and Methods of Studying Cnderground Insects Jour of Eiton Entom, 8, 140-14!).

31. Drivet, Leox Nouvelles (Mservations sur lo Mosquero ou Nid D'Aragnees Sociales Bull. de la Societe Nationale D'Alccitizutciton de France, 62, $240-249$.

32. Dexx, $L$ H Observations on the Preoviposition, Oviposition and Incubation Periods of Lermacenton mtens un Panama. Entom. Neus. 26, 214-219.

33. Essexblerg, C. The Habits and Natural History of the Backswmmers, Norometzdac Jour. of Anemal Behar., 5, 381-390

34. Escexisenc, C The Hahits of the Water-Strider Gerres remages Jour. of Anemal Behav., 5, 397-102

35 Fantila1, H. B Insert Pests and War Nature, 95, 2t55-266.

36 FELT, E P. The Gall Midges of the Pine Bull Erooklym Entom. Soc., 10, $7 \pm-76$

37. Flozrshim. Some Notes on the Papihonids. The Entomologist Lordon, $1915,225-229$

38. Fonbes, s. A. The Ecological Foundations of Applied Entomology, Ann. Entom Soc. of Amer, 8, 1-19.

40. Foster and Jones. The Life History and Habits of the Pear Thrips in Californla $U$. S. Dept. of Agm., Bull, 173.

41. Frisci, K. Ton. Der Farbensinn und Formsinn der Biene. Zool. Jahrb., Abt f. Allegmein Zool., 35, 1-183.

42. Froнawк, F. W. Hibernating Examples of Vanessa antropa. The Entomologist London, 1915, 242-243.

43. Fulleg, Clatde. Observations on some South African Termites. Ann. of the Natal Museum, 3, 329-504. 
44. Fuxkhouser, W D. Life History of Vanduzea arquala Say (Membracidae). Psyche, 22, 183-199

45. GerhandT, W Copulation und Spermatophoren von Grylliden und Locustiden Zool. Jahrl Abth. $f$. Syst, 36, 1-64

46. Grllett and Bragg Notes on Some Colorado Aphids Havme Alternate Food Habits. Jour. of Econ. Entom, 8, 97-103.

47. Girault, A. A. A Brdbug Attacking Human Beings. Entom. N'cws, 26, $221-222$

48. Giratlt, A. A Duration of the Pupal Stage of Adala 15-punctata. Entom. Neus, 26, 223 .

49. Grmitur, A. A. Geotaxis in Truchogramma minutum Riley. Entom. News, 26,131

50 Ginacle, A A. Larva of Helootus obsoluta Fabricius Eats a Larva of Empretza. Ertome Town, 26, 22ti-22t.

51 Gldser. R W. Bactorial Diseases of Caterpultars Psyche, 21, 1S1-190

52. H. A 13 A Frui Fly Attacking Papaw Fruts Agr Nell Babados, 14,106

53. Hadnox, K. On the Methods of Feeding and the Mouthparts of the Larva of the Glow-Worm (Lampyris noctuluca). Proc. Zool Soc London, 1915, $77-85$.

54. HADws, S Warble Flies A Further Contribition on the Bology of Hypoderma lencatum and $H$ borks Partatologm, $7,331-338$

55 H.ivers's, J L Pink Katyduds and the Inheritanes of Pank Coloration.

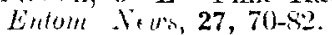

56. Hargatr. C W Obsirvations on the Behavior of Butterfles Jour of 1almal Krhar, 5, 250-25

57 Hararives, is The Lifs-History and Habits of the Greenhouse White-I'ly

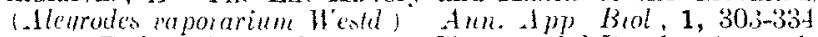

is "Hriscr. R W The Advantatges Chrysomelad Beetles Fecure by Concealung

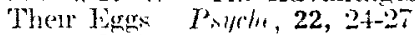

59. Huwrty. C A An Early Reference to the Relations of Insects to Disease The Carad Entom, 47, 396-399

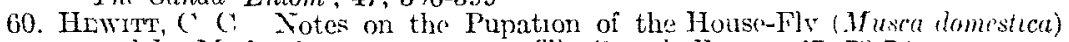
and Its Mode of Overwmtermg The ('anard Entom, 47, 73-7s

61 Hewit, $\mathrm{C} C$ Obscrvations on the Feedung Habit of the Stable-Fly Trans. Rivizal icuel of Canark, $8,37-12$.

62 Hewre, C C The House Fly Its Structure, Habits, Development, Relaton to Disease and Cont rol Cantridge, $352 \mathrm{~mm}$.

63 Hewit, $T \mathrm{~T}$ The Larva and Puparium of the Fruit-Fis Aore Neus Barbado: 14. 313-316;

61 Hnist, On Some Xew Learne Parasites on Rats Bull. Entom Rescarch, $6,183-190$

65. How LeTr, F. MI. The Chemeal Reactions of Fruit-Fies Bull of Entom Risterch. 6, $297-306$

66 Hrslup. J A Observations on the Life History of Mercanthe contracta, Psyche, 22, 41-48

67 Illingworth, J. F. Notes on the Habits and control of the Chincken Flea (Echadnophaqa gallinarea) Jour. of Econ Entom, 8, 492-495.

68. Texxeds, C. H Notes on the Life History and Eeology of the Dragonfles (Odonata) of Washington and Oregon Proc. L.S. Nal Hist Mus, 49, 259-345

69. Inxcald. E The Effect of Color on the Thistle Butterfly. Nature Study Rocrev, $11,340-3 \pm 1$.

70. Fxis, F Commensalism in Desmometopa. Proc. Entom Soc. Wash., 17, $117-121$

71. Kixab, F. The Secretions Employed by Rhvnchophorous Larvae in CocoonMaking Proc. Entom. Soc of $W$ ash., 17, 154-158.

72. K KAB and Busch. Mosquitoes and Sewerage Disposal. Jour. of Agri. Research, $2,333-338$. 
73. Krecker, F. H. Phenomena of Orientation Exhibited by Ephemeridae. Brol. Bull., 29, 381-388.

74. Krevare, E. Physiologiseh-Biologiche Studien-Ueber die Bedeutung der Luft des Flythrabraums bel Dysticus. Acta Unzersitaszs Lundensis (nova serzes). 10, No. 13, $20 \mathrm{pp}$.

75. Leceaga, E. How War Has Been Waged in Mexico against the Mosquito. The Amer. Jour. of Tropical Diseases and Preventative Medicine, 2, 118-123.

76 Leuderwand, H. Zur Lebensweise Braslianischer Cincindeliden. Zert $f$. I'rss. Insektenbrol., 11, 25-27

77. Lloyd, J. T Wood-Boring Trichoptera. Psyche, 22, 17-21.

78. Lovell, J. H. A Prelimmary List of the Anthophlous Coleoptera of New England. Psyche, 22, 109-117.

79. Lovell, J. H. Insects Captured by the Thomssidae. The Canad. Entom., 47, 115-116.

80. Loveln, J. H The Origin of Anthophily among the Coleoptera. Psychc, 22, $67-84$

81. Lyon, Harold Does the House Fly Hibernate? Psyche, 22, 140-141.

82. Lyun, Harold. Notes on the Cat Flea (Clenocephalus felis Bouche). Psyche, 22, 124-132.

83. McAtee, W. L. A Remarkable Flight of Caddis Flies and Chironomids. Scrence, 42, 694-695.

84. McDrrmotr, F. A. Notes on the Reaction of the House-Fly to Air Currents. Jour of Anzmal Behan'., 5, 73-74.

85. McInion, $\mathrm{N}$ E. The Olfactory Sense of Coleoptera Brol. Bull., 28, 407-460.

86. McSHANE, H. The Phlebotomys papatsch the Transmitter of the Three Days Fever. Amer. Jour. of Trop. Diseases and Preventatne Mcd., 2, 815-818.

87. MACFIE, J. W. S Observations on the Bionomies of Stegomyza fascrata. Bull. Entom. Research London, 6, 205-230

88. MANN, W M. A Cursorial Tick. Psyche, 22, 60

89 Mancovitur. S. The Biology of the Juniper Berry Insects, with Description of New Species Ann Entom. Soc of Amer., 8, 103-18s

90. Mitzanain, M. B. An Experiment with Stomoxys calchtrans in an attempt to Transmit a Tritaria of Horses in the Philippines. Amer Jour. of Trop. Diseases and Preventatuve $\mathrm{Med}, 2,759-76$.

91. Nanayama, $S$ Notes on the Life-Hustory and Habits of the Rose Scale A ulacaspre rosae Jour. of Entom and Zool., 7, 45-54.

92. Nicholson, C Hibernation of Vespa vulgaris The Entom. Record, 1915, $11 \tilde{-116}$

93. Nores, Alice A. The Brology of the Net-Spinning Trichoptera of Cascadilla Creek. Ann Entom. Soc. Amer., 7, 251-271.

94. NCTALI, G. H. F. Observations on the Biology of the Ixodidae; Artificial Parthenogenesis in Ticks Parastology, 7, 408-461.

95. Pearsi, A. S. and White, Gertrude M. Recent Literature on Tropisms and Instinctive Activities Psychol Bull, 12, 231-290

96. Picter, A. Reactions Thermotropiques chez les Insectes (Resume) Compt. Rendu Sciences de la Soc de Physique et d' Histoure Naturelle de Geneve, 31, $54=56$.

97. Prerce and Cusbanan. A Few Notes on the Habits of Parasitir Hymenoptera Proc. Entom. Soc. of TWashington, 17, 164-167.

98. PrNG, C. Some Inhabitants of the Round Gall of the Goldenrod. Jour. of Entom. and Zool., 7, 161-179.

99. Ratrmay, R. H Notes on the Larval and Pupal Stages in some of the Sesildae. The Entomologist, London, 1915, 9-12.

100. Rac. Phil. Duration of Pupal and Adult Stages of the Meal Worm Tenebro obscurus Linn. Entom. News. 26, 154-157.

101. RAU, PHIL. The Ability of the Mud-Dauber to Recognize Her Own Prey. Jour. of Anemal Behav., 5, 240-244.

102. Rat, Pmil. The Longevity and Mating Habits of Dicromorpha viridis Scud. Eniom. News, 26, 27-28. 
103. Richardsox, C. H. An Observation on the Breedng Habits of Stigmus conestogorum Rohwer Psyche, 22, 104-105.

104 Regites, A. G. Life History of Obera tripunctala. Jour. of Econ. Entom., 8, 79-8.5

105. Sanders, Geo E Carnyorous Habits of Xylma Bethuner G. \& R. Canad. Entom., 47, 183-184

106. SchWanz, Ersst. Observations on the Habits of Catocala thtanta Dodge. Entom. Newe, 27, 67-69.

107. Severin, Henry H P. and H.1rry C. The Stimuli which Cause the Eggs of the Jeaf-()vipositing Tachindae to Hatch. Psyche, 22, 132-137.

108. Shaxios, R. C. Captures of the Syrphid Fly Merapiodes idlosus Proc. Entom. Soc. of Washington, 17, 14i-148.

109. Shelford, $Y$ Suggestions as to the Original Habitat and Distribution of Various Native Insect Pests Jour. of Econ. Entom., 8, 171-174.

110 Sjostedt, Y. La Construction des Xids chez les Insectes Revu' Gen. des Scences P'ures et A Aplaques, 26, 85-90.

111. Snixxer, Hranr. How does the House-Fly Pass the Winter? Entom. Ncu's, $26,263-264$

112. Sxyorr. T E. Brology of the Termites of the Eastern United States, with Preventative and Remedial Metsures Bureau of Entom., U.S. Dept. of Agri, Bull. 94, 13-85

113. StellwaAg, F. Ueber das Biogenetische Grundgesetz im Leben der Insektenstaaten Naturuss. Wochensch, 14, 426-127

114 StellwaAG, F. Zum Farbensinn der Bienen Liefert Kranchfeld in Biologischen Zentralblatt. Naturwess Wochenschroft, 14, 427-42S.

115 Stephex, J. Die Spinnkunst der Raupen. Natier, Halbmonatschreft f. alle Natueftreund, 1915, 427-430.

116. Strutevaxt. A H. Experiments on Sex Recognition and the Problem of * Sexual Selection un Drosophlia Jou. of Animal Behat., 5, 351-366.

117. Torre Butero, J. $R$ de lia. Phototropism in Heteroptera. Bull Brooklyn Entom, Soc, 11, 90-96.

118. Tursxis. C H. Literature for 1914 on the Beharior of Spiders and Insects other than Ants Jour. of Anmal Behar, 5, 415-145

119. Turser, C H. Notes on the Behavior of the Ant-Lion with Emphasis on the Freding Activitues and Letismulation. Biol Bull, 29, 277-307

120 Trrner, C. L Bredng Habits of C'uthophalus laters, the Camel Cricket Bull Was. Nat It sst soc, 13, 32-41.

121 Walrexgrex, H. Physiologischblologische Studien ueber die Atmung der Aeschnalurven Acta $\tau^{*}$ nerersetates Lundensts, 10, No. 8, $28 \mathrm{pp}$ )

122 Wasmaxx and Valkmentira. Ein Neues Buch Ueber das Leben und Wesen der Bienen Die Naluruesssh., 38, 48.5-488, 497-500.

123 Webster, F. M Nigrating Notes on the Milkweed Butterfly The Canar. Entom., 47, 400

124. WeIss, H. B. Notes on the Tropic Reactions of Macrodactylus subsprnosus. The Canad. Entom., 47, 152.

125. WhEELER. W. M Ants and Bees as Carriers of Pathogenic Micro-Organisms Amer. Jour of Trop. Diseases and Prevertatave Med., 2, 160-168.

126. Wheeler, $W$. $M$ and Wrrmams, F. $X$. The Lummous Organ of the New Zealand Glow-Worm Psyche, 22, 36-43

127. Williays, C. D. The Pea Thrips (Kalothrips robusius) Ann. App Biol, $1,222-246$

12S. Woopworti, C W. The Rate of Hatch of Scale Insect Eggs. The Canad Entom., 47, 98-99.

130 ZETEK, $J$ Behavior of Anopheles albimanus Wied and tarstmaculata Goeld. Arin. Entom. Soc. of Amer., 8, 221-271. 